\title{
The Development of Elementary School Social Science Course Teaching Materials on Mobile-Learning Based Android to Increase College Students' Academic Performance
}

\author{
Husna Parluhutan Tambunan*, Risma Sitohang and Yusra Nasution
}

\author{
PGSD FIP Unimed, Jl. Williem Iskandar Psr V, Medan Estate, Medan, Indonesia \\ *Email: husnaparluhutan@unimed.ac.id
}

\begin{abstract}
This study aims to: (1) develop teaching materials for Elementary School Social Science course on mobile learningbased android and (2) know the feasibility level of the developed teaching materials. This type of research is Research and Development by adapting the modified Borg \& Gall model into five stages, namely information gathering, product planning, product development, product validation, and product evaluation. The results showed that (1) software of teaching material for Elementary School Social Science course on mobile learning-based android had been compiled based on input from validators, and (2) the teaching materials for the Elementary School Social Science course developed are considered suitable for use in learning in terms of material aspect and design aspect. The assessments from the experts are as follows: the validation result of the material expert for the content aspect is in very good qualification (85.6\%), the material expert validation result for the presentation aspect is in very good qualification $(85.9 \%)$, the material expert validation result for the language aspect is in very good qualification $(86.4 \%)$ and the average validation result from design expert in very good qualifications $(86.1 \%)$
\end{abstract}

Keywords: Teaching materials, Mobile learning, Android.

\section{INTRODUCTION}

Information and Communication Technology (ICT) is developing very rapidly along with the demands of various human needs. Human life that is full of information needs creates dependence on the ICT field to fulfill it. The presence of ICT is able to facilitate various human activities such as business, health services, work, daily needs, and including the field of education. The author [1] said that currently, ICT is not only alternative technology, but ICT is an inseparable partner in various fields in improving life processes, one of which is the field of education. The world of education cannot be separated from the learning process which includes educators, students, and the learning environment that influence each other.

The use of mobile learning in the learning process is considered to have a big impact on improving the quality of learning. Because the meaning of mobile learning itself is a learning media that allows educators to deliver teaching materials to students using mediabased android where there is two-way communication in the use of mobile learning.
The most basic reason in this study is supported by the condition of college students in the Elementary School Teacher Education (PGSD) study program Faculty of Education (FIP) State University of Medan (Unimed), which is known that the average college students have an android. Based on the observation made, college students who have android smartphones use their smartphones to visit social media such as BBM, Twitter, Facebook, Line, WhatsApp, and games rather than things related to the subject matter, whereas android smartphones can be used as alternative learning media to improve college students' understanding of learning materials. The widespread use of smartphones by college students encourages the existence of a learning innovation by utilizing android smartphones to improve college students' academic performance in learning and can support the achievement of college students' understanding.

Based on the background described above, the problem that becomes the study material in this study is how do lecturers develop learning media on mobile learning-based android to improve the college students' academic performance in PGSD study program? The 
purpose of this research is to produce teaching materials for Elementary School Social Science course on mobile learning-based android to increase college students' academic performance in PGSD study program.

\section{METHODS}

This study uses the Research and Development (R\&D) method. The research and development (R\&D) method according to the author [2] is a research method used to produce a certain product and test the effectiveness of the product. The research aims to develop and test the learning material on mobile learning-based android which is carried out in the learning process of Elementary School Social Science course at the PGSD FIP Unimed.

This research model was carried out with 5 steps adapted from the Borg \& Gall development model [3]. The steps taken in this research are (1) information gathering (2) product planning (3) product development, (4) product validation, and (5) product evaluation. The academic performance of the college students being discussed in this study is limited to learning motivation and cognitive learning outcomes. This research was carried out only for product validation, the evaluation stage was not carried out due to time constraints.

The instruments used in this study were validation sheets and interviews. The interview conducted is a preliminary study for data collection in exploring the problems to be studied. The research data were analyzed to determine the feasibility (validity) of Elementary School Social Science course teaching materials on mobile learning-based android. The validity of the teaching materials that have been developed can be seen from the validation sheets filled in by the expert validators and the results of questions and answers during the validation process.

\section{RESULTS AND DISCUSSION}

\subsection{Information Gathering}

At this stage, information is collected in the development of mobile learning-based android in PGSD FIP Unimed. This information collection is done by directly observing the lecturers who teach Elementary School Social Science course, either by interviewing or filling out a questionnaire.

\subsection{Product Planning}

At this planning stage, the researcher designed and prepared teaching materials for Elementary School Social Science course on mobile learning-based android. The design stage compiles the specifications of the resulting product.

\subsection{Product Development}

At this stage, the development of mobile learningbased android in Elementary School Social Science course teaching materials is carried out. The product is designed so that can be used in the learning process and become one of the media that supports learning.

\subsection{Product Validation}

At the product validation stage, a trial is carried out in stages and continuously, which consists of a learning design expert test, and content expert test, presentation, and language. The product that has been made is named the Elementary School Social Science course teaching material-based android. The steps in this test, namely: (1). determine the assessment indicators used to assess the products that have been made, (2). develop product feasibility test instruments based on predetermined assessment indicators, (3). carry out product feasibility tests to learning design expert test, and content expert test, presentation, and language, (4). analyze the results of product feasibility tests and make improvements and (5). Show the repaired product to learning design expert test, and content expert test, presentation, and language. The validation results from learning design expert, and content expert, presentation, and language can be seen in Table 1 below:

Table 1. The Validation Result from the aspect of content, presentation, and language expert

\begin{tabular}{lcc}
\hline \multicolumn{1}{c}{ Assessment Aspect } & $\begin{array}{c}\text { Percentage of } \\
\text { validator ratings }\end{array}$ & Category \\
\hline Content Eligibility & $85.6 \%$ & Very good \\
Presentation Eligibility & $85.9 \%$ & Very good \\
Language Eligibility & $86.4 \%$ & Very good \\
\hline
\end{tabular}

Table 2. The Validation Result from the learning design expert

\begin{tabular}{lcc}
\hline $\begin{array}{c}\text { Assessment } \\
\text { Aspect }\end{array}$ & $\begin{array}{c}\text { Percentage of } \\
\text { validator ratings }\end{array}$ & Category \\
\hline Reliable & $86 \%$ & Very good \\
Maintainable & $87.5 \%$ & Very good \\
Reusable & $86.5 \%$ & Very good \\
Average & $\mathbf{8 6 . 1 \%}$ & Very good \\
\hline
\end{tabular}

The design of the development of teaching materials for Elementary School Social Science course on mobile learning-based android consists of 4 stages, namely gathering information, product planning, product development, and product validation. At the product validation stage, expert validation is carried out. The validation result of the material expert for the content aspect is in very good qualification (85.6\%), the material expert validation result for the presentation aspect is in very good qualification $(85.9 \%)$, the material expert validation result for the language aspect is in very good qualification (86.4\%) and the average validation result from design expert in very good qualifications $(86.1 \%)$. 


\section{CONCLUSION}

This research produces Elementary School Social Science course teaching materials on mobile learningbased android which was developed through R\&D (Research and development) method. The developed teaching materials obtained very good category, both in terms of content, presentation and language as well as design aspect. The developed Elementary School Social Science course teaching materials are expected to increase students' academic performance.

\section{REFERENCES}

[1] Arifin, Zainal. 2008.Educational Research Technology, Surabaya : Lentera Cendikia

[2] Sugiyono 2015 Metode Penelitian Pendidikan: Pendekatan Kuantitatif, Kualitatif, dan $R \& D$ (Bandung: Alfabeta)

[3] Borg, W. R., \& Gall, M. D. (1983). Educational research: an introduction. London: Longman, Inc. 